\title{
Fishing of Norway lobster Nephrops norvegicus (Linnaeus, I758) (Decapoda Nephropidae) in Algerian western waters
}

\author{
Djamel Bekrattou, Salim Mouffok*, Noureddine Benaissa \& Mohammed Bouderbala
}

Laboratoire Réseau de Surveillance Environnementale, Département de Biologie, Faculté des Sciences de la Nature et de la Vie, Université Oran 1, BP 1524 El Menaouar, Algeria

"Corresponding author, e-mail: halieutsalim@yahoo.fr

\begin{abstract}
A frequently occurring species with high market value in Algeria, the Norway lobster Nephrops norvegicus (Linnaeus, 1758) (Decapoda Nephropidae) has attracted the interest of many professional fishermen. Fishery for this species has been growing rapidly in recent years. In this work, we collected data on the eco-biology, production, and monitoring of fishing effort and calculated yields. Our main objective is to provide an introduction to the fishing activity of this crustacean decapod in western Algeria, to provide a database for further studies of the lobster stock, and to contribute to the improvement and development of lobster fishery in Algeria.
\end{abstract}

KEY WORDS

Algeria; capture; effort; eco-biology; Nephrops norvegicus; performance.

Received 23.12.2018; accepted 20.04.2019; published online 24.05.2019.

\section{INTRODUCTION}

In Algeria, due to the absence of any form of crustacean farming, the total shrimp production corresponds to over $90 \%$ fishing. Three shrimp species of high commercial value are caught that, in order of abundance, are: Aristeus antennatus (Risso, 1816) (Aristeidae), Parapenaeus longirostris (Lucas, 1846), and Penaeus kerathurus (Forskål, 1775) (Penaeidae).

Due to the considerable economic value, some crustaceans have attracted the interest of many professional fishermen. This is the case for the Norway lobster Nephrops norvegicus (Linnaeus, 1758) (Decapoda Nephropidae) which leads a demersal life, living on sandy mud bottoms (Sarda \& Aguzzi, 2012). Its bathymetric distribution is wide, ranging from $15 \mathrm{~m}$ to $800 \mathrm{~m}$ (Farmer, 1972) but, typically, from 180 to $500 \mathrm{~m}$ (Abello \& Sarda, 1982; Dintheer, 1982; Orsi Relini \& Relini, 1985).
On the biology and fishing of $N$. norvegicus, several studies have been published for the Mediterranean Sea in Spain by Sarda (1998), Sarda et al., (1998), and Aguzzi et al. (2004, 2009a), in France by Fontaine \& Warluzel (1969), Morizur et al. (1981), Morizur (1983), and Macher et al. (2008), and in Greece by Castro et al. (1998).

In Algeria, N. norvegicus is abundant in the extreme West (from Ghazaouet to Bouzedjar) and a first estimate made in 1982 on the level of this marine zone reveals a high biomass (ISTPM, 1982). In this coastal area of western Algeria, this crustacean is found on the continental shelf edge between 180 and $550 \mathrm{~m}$ depth, with a higher density between 280 and $400 \mathrm{~m}$ (CGPM/GFCM, 1982; Massuti et al., 2003). However, this Arthropod becomes gradually scarce as we move from Habibas Islands (western Algeria) towards the eastern country coast.

We tried to get as much information as possible on the eco-biology and fisheries of $N$. norvegicus 
in order to exploit the results as a data basis for future studies and contribute to the improvement and the management of these crustaceans fisheries in Algeria.

\section{MATERIAL AND METHODS}

\section{Study area}

In Algeria, the lobster is caught in the western region of the country, which extends on approximately $5000 \mathrm{~m}^{2}$ all along the $80 \mathrm{~km}$ of coastline limited to the West and the East respectively by the meridian lines $2^{\circ} 00^{\prime} \mathrm{E}$ and $2^{\circ} 30^{\prime} \mathrm{E}$ and $2^{\circ} 00 \mathrm{E}$ and $2^{\circ} 30^{\prime} \mathrm{E}$ and North by the parallel $35^{\circ} 20^{\prime} \mathrm{N}$ and $35^{\circ} 40^{\prime} \mathrm{N}$ (Fig. 1).

\section{Sampling}

Twenty-one sea trips have been carried out on a professional trawler operating in a regular way from June 2011 to April 2012 on our study area (Cape Noe until Habibas Islands; Fig. 1) with 617 specimens gathered.

Data collection on fishing for this lobster is based mainly from surveys and personal investigations in the field, obtained from personal commercial fisheries statistics, and also gathered from the concerned management and fishing resources services (DPRH). The information on the capture sites and the sorting characteristics, as well as other data on the lobster fishery, were collected from some skippers. These data provided additional information to those presented in Table 1 on the various areas restricted for the Norway lobster fishing activity and bathymetric limits (Table 1). The preliminary treatment of collected specimens were carried aboard a trawler. After sorting by sex, each individual was measured using a caliper and weighed by a precision balance. For females, the ovaries stages maturity was determined by macroscopic observation according to the Farmer scale $(1972,1975)$. We adopted three gonadic stages (Table 2).

We then analyzed the various data obtained through different models and equations below: the overall sex ratio, the sex ratio according to size, and the sex ratio according to seasons.

It has been calculated a $X^{2}$ heterogeneity test, the risk of a degree of freedom and $p<0.05$ significance, using the STATISTICA Software (StatSoft
Inc., 2001) to determine whether the predominance of each sex in each class size and during all sampling months are significant or not.

The length at first maturity (L 50) is the length at which $50 \%$ of females are mature (Fontaine \& Warluzel, 1969; Conand, 1977). To provide details on the reproductive cycle and the lobster laying, $\mathrm{L}$ 50 was calculated as follows:

$$
L_{50}=\frac{S_{1}}{S_{2}}
$$

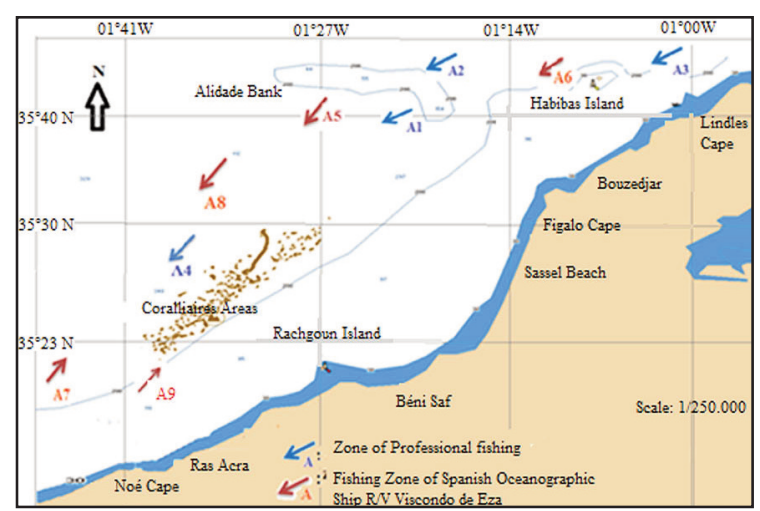

Figure 1. The Nephrops norvegicus geographical distribution in western Algeria with the fishing areas.

\begin{tabular}{|c|l|l|l|l|}
\hline A1 & $35^{\circ} 41^{\prime} 000^{\prime \prime} \mathrm{N}$ & $01^{\circ} 21^{\prime} 600^{\prime \prime} \mathrm{W}$ & 336 & 357 \\
\hline $\mathrm{A} 2$ & $35^{\circ} 41^{\prime} 565^{\prime} \mathrm{N}$ & $01^{\circ} 21^{\prime} 770^{\prime \prime} \mathrm{W}$ & 362 & 383 \\
\hline $\mathrm{A} 3$ & $35^{\circ} 41^{\prime} 000^{\prime \prime} \mathrm{N}$ & $01^{\circ} 22^{\prime} 560^{\prime \prime} \mathrm{W}$ & 430 & 455 \\
\hline $\mathrm{A} 4$ & $35^{\circ} 47^{\prime} 107^{\prime \prime} \mathrm{N}$ & $01^{\circ} 15^{\prime} 967^{\prime \prime} \mathrm{W}$ & 330 & 463 \\
\hline A5 & $35^{\circ} 45^{\prime} 165^{\prime \prime} \mathrm{N}$ & $01^{\circ} 19^{\prime} 461^{\prime \prime} \mathrm{W}$ & 626 & 650 \\
\hline A6 & $35^{\circ} 47^{\prime} 107^{\prime \prime} \mathrm{N}$ & $01^{\circ} 15^{\prime} 967^{\prime \prime} \mathrm{W}$ & $\mathbf{5 3 0}$ & 863 \\
\hline A7 & $35^{\circ} 30^{\prime} 917^{\prime \prime} \mathrm{N}$ & $01^{\circ} 38^{\prime} 692^{\prime \prime} \mathrm{W}$ & 376 & 380 \\
\hline A8 & $35^{\circ} 37^{\prime} 820^{\prime \prime} \mathrm{N}$ & $01^{\circ} 37^{\prime} 274^{\prime \prime} \mathrm{W}$ & 441 & 454 \\
\hline A9 & $35^{\circ} 22^{\prime} 025^{\prime} \mathrm{N}$ & $01^{\circ} 49^{\prime} 970^{\prime \prime} \mathrm{W}$ & 321 & 359 \\
\hline A10 & $35^{\circ} 40^{\prime} 113^{\prime \prime} \mathrm{N}$ & $01^{\circ} 28^{\prime} 464^{\prime \prime} \mathrm{W}$ & 404 & 419 \\
\hline
\end{tabular}

Table 1. Fishing areas for Nephrops norvegicus in the bay of Beni Saf (western Algeria).

\begin{tabular}{|c|c|l|}
\hline Stage & ovarian Color & \multicolumn{1}{c|}{ Other characteristics } \\
\hline $\mathbf{1}$ & White & - Threadlike(filiform) ovaries, well separated \\
\hline $\mathbf{2}$ & Pale green & $\begin{array}{l}\text { - Ovaries having developed lateral wings } \\
- \text { Visible oocytes } \\
\text { - Vitellogenesis }\end{array}$ \\
\hline $\mathbf{3}$ & White and green mottled & $\begin{array}{l}\text { - Ovaries during shrinkage } \\
\text { - Oocytes being resorbed }\end{array}$ \\
\hline
\end{tabular}

Table 2. Summary outline of maturity stages applied to $\mathrm{Ne}$ phrops norvegicus females and the equivalent macroscopic characteristics. 


\section{Growth study}

The objective of this part is to determine the characteristic of living organisms, such as population size structure, growth and age of $N$. norvegicus in the targeted area of this study. There are several mathematical models to express the growth in crustaceans. A detailed review was made by Beverton \& Holt (1957), Ursin (1967), Gulland (1983), Sparre \& Venema (1996) and Pauly \& Moreau (1997). However, the most common model is that of Von Bertalanffy (1938):

$$
L t=L \infty\left[1-e^{-k\left(t-t_{o}\right)}\right]
$$

L $\infty$ is the theoretical maximum height (in $\mathrm{mm}$ ), Lt is the size (in $\mathrm{mm}$ ) at age $\mathrm{t}$, while $\mathrm{k}$ is the growth coefficient.

For the assessment of these parameters, the program LFDA (Kirkwood et al., 2001)was applied to monthly catches body length using ELEFAN method. As the calculations of $\mathrm{k}$ and $\mathrm{L} \infty$ growth are correlated, we will determine $\varnothing$ using the formula of Pauly \& Munro (1984):

$$
\Phi=2 \cdot \log L_{\infty}+k
$$

\section{Fleet and fishing effort}

To identify the best fishery (fleets and fishing effort), we consulted archives at the Fisheries and Fish Resources Department (DPRH) and two fishing antennas at both Bouzedjar and Beni Saf fishing ports located in our study area (Fig. 1).

The data collected was used to get catches per unit effort equal to the fishing effort split by the boats number or $\mathrm{E}=$ weight in ton/day.

In addition, daily monitoring (personal observations of the trawler landings) was used to calculate the standardized CPUE.

\section{Associated fauna}

The study of the associated fauna allowed, first, to make an inventory and to know the captured species and, secondly, to determine the species composition and calculate their relative abundance which is equal to the number of the individual species on the total number of all species in percentage.

\section{RESULTS}

According to Kartas \& Quignard (1984), the sex ratio is one of the parameters that helps, within a certain limit, the reproductive capacity of species in their natural environments. In other words, this index represents the abundance of one sex compared to another.

In our sample of 617 Norway lobsters, the sex of each individual has been determined (431 males and 186 females). The total sex ratio is $69.85 \%$, with a total femininity rate of $30.15 \%$ clearly indicating a sex-ratio in favor of males. From the populations and from females and males percentages in $N$. norvegicus by size class, we illustrate the size abundance curves in figure 2. Figure 3 represents graphically the monthly variations of sex ratio; we noted that the males percentage remains quite dominant during the year.

Based on closer examination of the ovaries structure on a yearly cycle (June 2011-April 2012), we can say that the species spawning period studied in Beni Saf area takes place from November to April with a maximum phase of gonads maturation in March (Fig. 4).

The conclusion that emerges from figure 4 is that the size at first maturity is relatively variable depending on the geographical zone (Table 3), according to Cartes et al. (1993).

The analysis focuses on the distribution of the total sampled catches during the 11 months of work (June 2011 - April 2012). The LFDA Software (subroutine ELEFAN) (Kirkwood et al., 2001) was used for the calculation of the growth parameters values. The Tables 4 and 5 gives the values of $\mathrm{L} \infty, \mathrm{K}$ and t0 estimated for the target species, and then replaced in the Von Bertalanffy equation, as well as $\varnothing$ calculated in the present study.

Figures 5 and 6 show the fleet evolution at the two ports: Beni Saf and Bouzedjar fishing with bottom trawls over a period from 2002 to 2012 . We noticed from the two previous figures that the trawlers number during this period of 10 years of operation has increased from 11 to 48 at the Bouzedjar port. However, and for the same period in the Beni Saf port, the number fell from 39 to 36 : the reduction is due to an operational fleet transfer of 3 trawlers from Beni Saf to Bouzedjar port.

Annual landings from 2007 to 2012 (Fig. 7) and lobster catch per unit effort (CPUE) (Fig. 8) for 
fishing with bottom trawling increased from 2 to 24.5 tons, respectively, and from 0.4 to 4.1 tons per boat every year in the respective way. Furthermore, the average standardized CPUE for the port of Beni Saf showed a similar tendency, with higher values in summer and autumn.

Despite the imperfection of quantitative appreciations that can be drawn from a study of associated fauna (Fig. 9) by trawling (from a sea trip to another catch the number of individuals and the number of species are highly variable), the analysis of the results reveals that the Norway lobsters are the most abundant species, especially in the median area of the continental shelf between a depth of 250 and 400 meters. The captured fish in these bottoms relates for the most part to the Gadidae family: the most common species are Merluccius merluccius (Linnaeus, 1758), followed by Phycis blennoides (Brünnich, 1768). The most common cephalopod being the Octopus vulgaris (Linnaeus, 1758) and, for crustacean fauna, the Parapenaeus longirostris. Lastly, only commercial species smaller than the stated size, as the dogfish Scyliorhinus canicula (Linnaeus, 1758), remain.

\section{DISCUSSION AND CONCLUSIONS}

Our study was conducted over a period of 11 months (12 June 2011-11 April 2012) with a total sample of 617 Norway lobster specimens. We noted

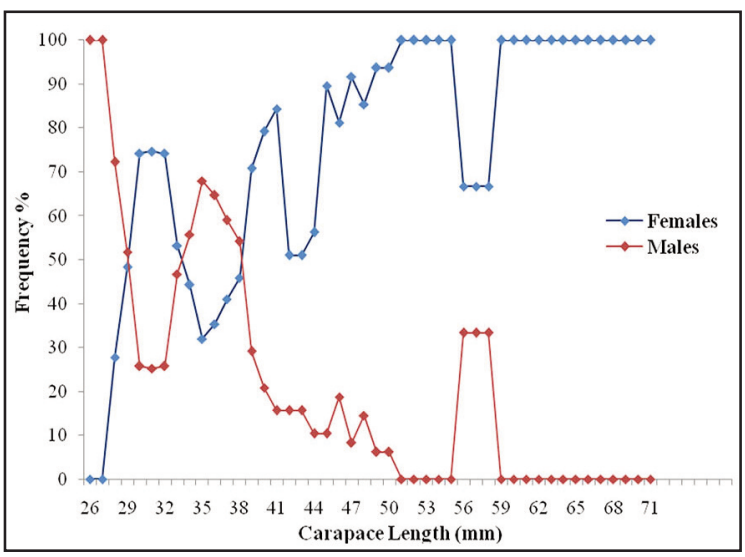

Figure 2. The Nephrops norvegicus males and females abundance curve vs size. The results of $X^{2}$ test highlight the predominance of the sexes according to the fishing months (* $\mathrm{p}<0.05$ significance) a difference in the sex ratio in favor of males during the sampling period (total male proportion = $69.85 \%$, females $=30.15 \%$ ), with males being significantly more frequent than females and from size $\mathrm{Lc}=47 \mathrm{~mm}$ we found only males. This could result in a slightly faster growth for males. Charuau (1978) formulated the hypothesis that female growth would be slowed due to less frequent molts. Another explanation of the difference in the sex ratio in favor of males would be due to the low proportion of females in the catch, because they are less active and often hide in burrows (Jukic, 1971; Froglia \& Gramitto, 1981; Orsi Relini et al., 1998; Ungaro et al., 1999).

For the determination of the reproductive cycle and the laying period, based on the ovaries structure observation over a complete cycle (June 2011April 2012), we can say that the $N$. norvegicus spawning period in Beni-Saf area occurs from November to April with the maximum gonads maturation phase in March. Our results are practically similar to those obtained by other cited authors. These clearly define the spawning period in the Spring and early Summer. This situation is common to the Mediterranean shore (Karlovac, 1953; Morizur et al., 1978; Froglia \& Gramitto, 1979, 1981; Sarda, 1985; Sarda \& Cros, 1984; Sarda, 1983a, b, 1985, 1991; Froglia \& Gramitto, 1988; Orsi Relini \& Relini, 1989; Sarda \& Valladares, 1990; Sarda \& Lleonart, 1993; Mc Quaid et al., 2006; Morello et al., 2009).

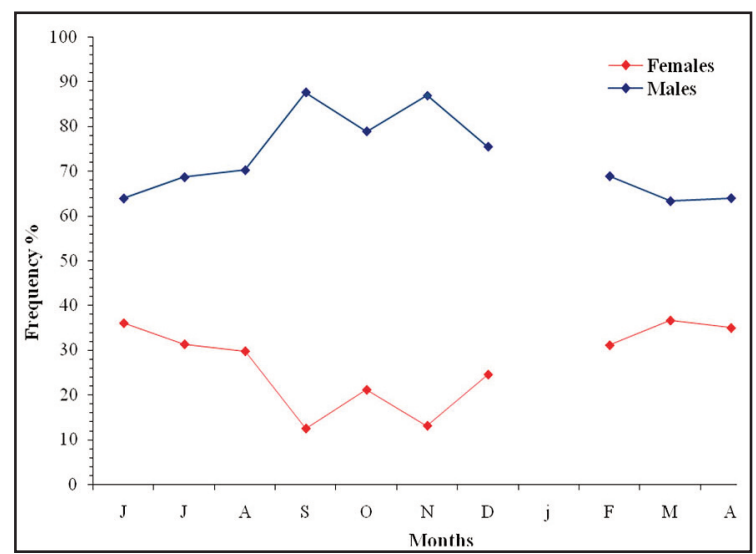

Figure 3. The Nephrops norvegicus males and females abundance curve vs size. The results of $X^{2}$ test highlight the predominance of the sexes according to the fishing months (* $\mathrm{p}<0.05$ significance). 


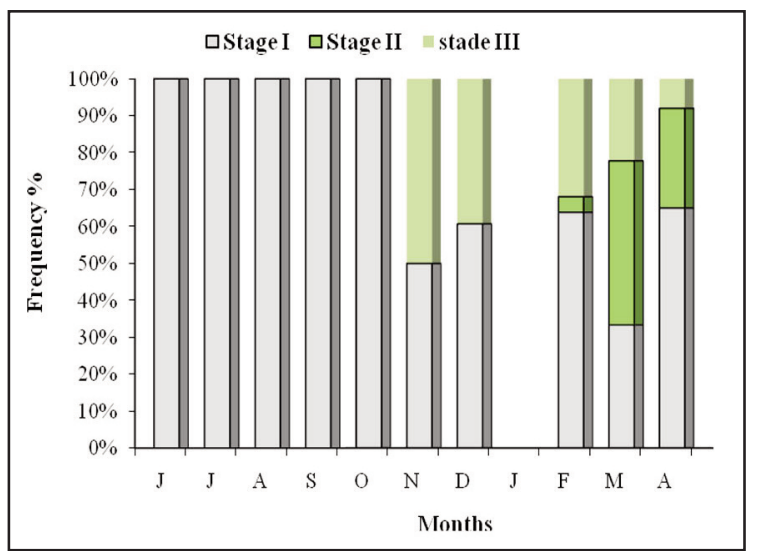

Figure 4. Percentages of different stages of sexual maturity in Nephrops norvegicus females.

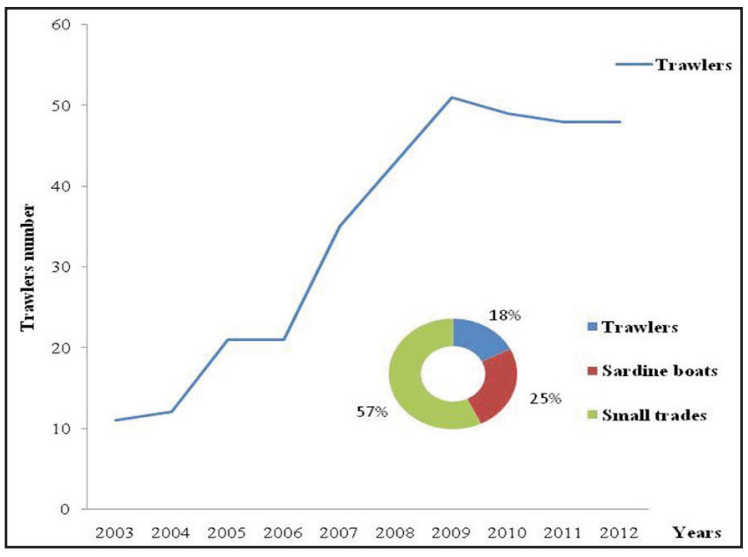

Figure 5. Annual evaluation of the trawlers number at Bouzedjar port.

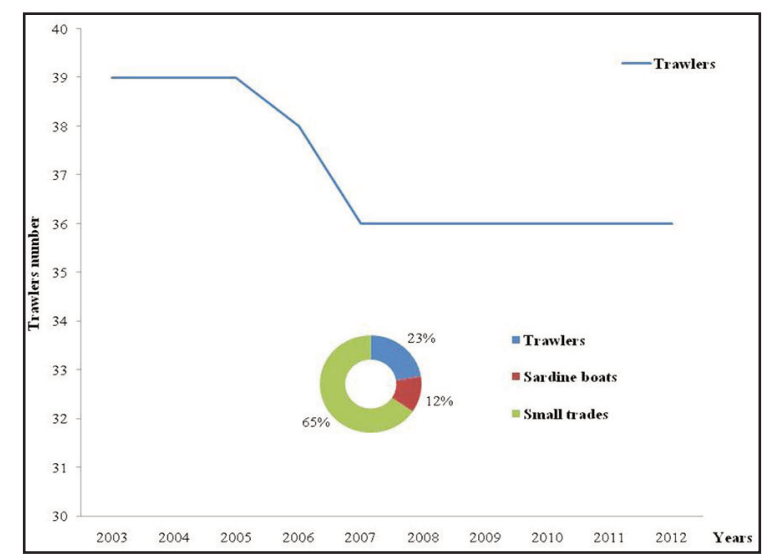

Figure 6. Annual evaluation of the trawlers number at Béni-Saf port.

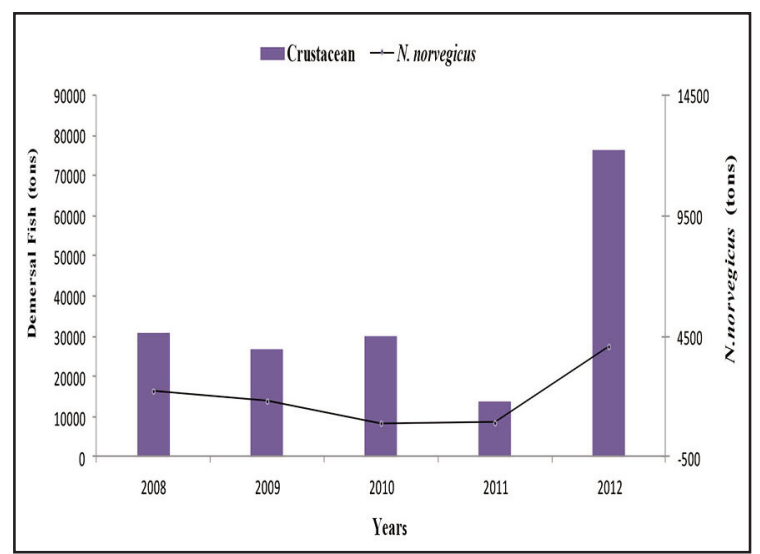

Figure 7. Annual unloadings of demersal fish and lobster Nephrops norvegicus.

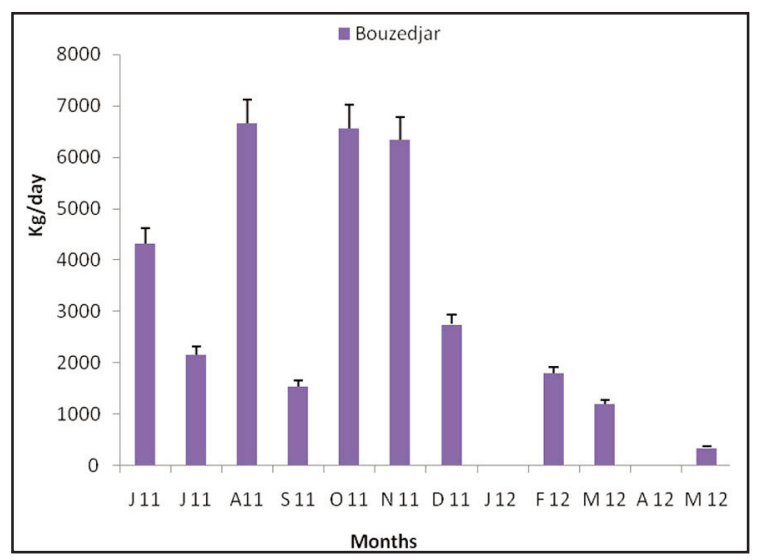

Figure 8. Monthly average of the standardized CPUE (with standard error) of Bouzedjar port.

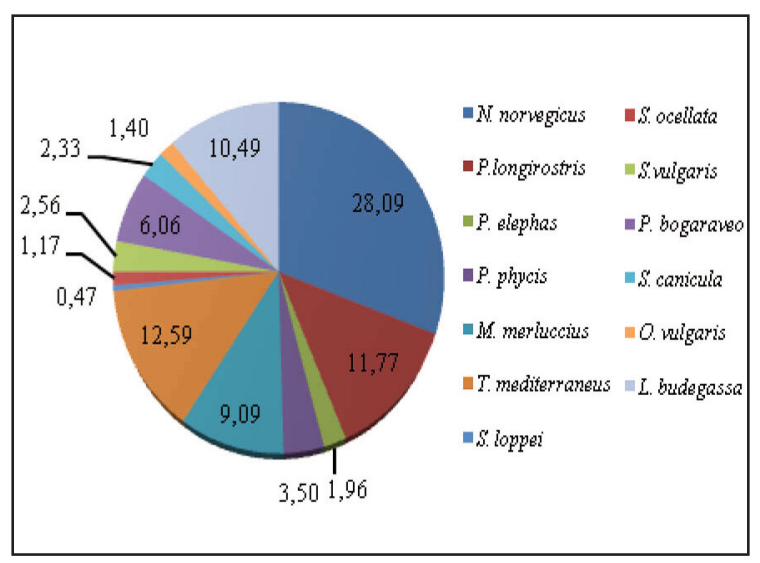

Figure 9. Nephrops norvegicus lobster associated fauna frequency. 
In the present work, the size at first maturity (L 50 ) is estimated at $33 \mathrm{~cm}$. These values are slightly overestimated because our samples come from commercial catches and not from experimental campaigns which operate on the whole bathymetric area. We can also add that the size at first maturity is relatively variable according to the geographical area (Cartes et al., 1993). Von Bertalanffy growth parameters are significantly different between the sexes, with higher values of the asymptotic length $(\mathrm{L} \infty)$, growth coefficient $(\mathrm{k})$, and the growth index $(\Phi)$ in favor of males. Therefore, the growth parameters estimated in the study area are in agreement with the low growth of the lobsters in the Mediterranean Sea (up to 25 to 32 years). This same model was also observed by Mytilineou et al. (1998), Sarda et al. (1998), Aguzzi et al. (2004), Cristo \& Castro (2005), and Morello et al. (2008).

The results obtained in this study on the various aspects of the eco-biology of the $N$. norvegicus in Algerian western waters reveal that the life cycle of this species is similar to that observed in other Mediterranean areas.

\begin{tabular}{|c|c|c|}
\hline Authors & Zone & Females (L50) $(\mathrm{mm})$ \\
\hline Morizur, 1981 & France & $27 \mathrm{~mm}$ \\
\hline Mc Quaid et al, 2006 & Ireland & $21 \mathrm{~mm}$ \\
\hline Aguzzi et al, 2004 & Spain & $23 \mathrm{~mm}$ \\
\hline Sarda et al, 1998 & Spain & $24 \mathrm{~mm}$ \\
\hline Elisabetta et al, 2009 & Italy & $31 \mathrm{~mm}$ \\
\hline Present work & Béni Saf (West Algeria ) & $33 \mathrm{~mm}$ \\
\hline
\end{tabular}

Table 3. Size of first sexual maturity (L50) of females in Nephrops norvegicus.

\begin{tabular}{|l|lccc|cccc|}
\hline \multicolumn{1}{|c|}{ Sex } & \multicolumn{4}{c|}{ Males } & \multicolumn{4}{c|}{ Females } \\
\hline Parameters & $\mathrm{K}$ & L $\infty$ & to & $\emptyset$ & $\mathrm{K}$ & L $\infty$ & to & $\emptyset$ \\
\hline Results & 0.16 & 77.50 & -0.16 & 4.574 & 0.36 & 62.14 & -0.67 & 4.030 \\
\hline
\end{tabular}

Table 4. Results of growth parameters for females and males of Nephrops norvegicus.

\begin{tabular}{|l|l|}
\hline Females & $L c_{t}=62.14\left(1-\mathrm{e}^{-0.36(t+0,67)}\right)$ \\
\hline Males & $L c_{t}=77.5\left(1-\mathrm{e}^{-0.16(t+0,16)}\right)$ \\
\hline
\end{tabular}

Table 5. Von Bertalanffy growth Equations.
In addition, these results show that the fishing effort, implemented in the marine fishing area for Norway lobster in western Algeria, is significantly lower than that carried in other Mediterranean areas where the fishing power deployed is largely higher. In addition, the virtual absence of fishing pressure in the continental slope (depths beyond $400 \mathrm{~m}$ ), resulted that the population of Norway lobsters at depths $>400 \mathrm{~m}$ remains an unexploited source and a potential resource for the Algerian fishing.

Les us remind that the Norway lobster fishing is a recent activity which started only in the last decade. According to Mouffok et al. (2008), this species fishing grounds have remained untapped until the end of the last century because of their distances from the ports, weather conditions, and lack of suitable equipment (cables not sufficiently long, non-performing board equipment, poorly qualified crew, old fishing fleet, very high cost of spare parts, etc.). Fishing in the area under study was only for a particular type of shellfish: the white shrimp Parapenaeus longirostris.

Moreover, N. norvegiucus has discouraged the toughest fishermen because of its adaptation to great depths, using burrows as refuge and moving towards zones difficult to reach by trawlers (coral zones).

\section{REFERENCES}

Abello P. \& Sarda F., 1982. The fecundity of the Norway lobster (Nephrops norvegicus) of the Catalan and Portuguese coasts. Crustaceana, 43: 13-20.

Aguzzi J., Bhamon N. \& Marotta L., 2009a. Modulation of activity rhythms in continental margin decapods by light availability and predatory behaviour of Nephrops norvegicus. Marine Ecology, 30: 366-375.

Aguzzi J., Sarda F. \& Company J.B., 2004. Feeding activity rhythm of Nephrops norvegicus of the western Mediterranean shelf and slope grounds. Marine Biology, 144: 463-472. https://doi.org/10.1007/s00227003-1221-6

Beverton R.J.H. \& Holt S.J., 1957. On the dynamics of exploited fish populations. Ministry of Agriculture, Fisheries and Food, London (United Kingdom). Fisheries Investigations, 19: 1-533.

Cartes J.E., Sarda F., Company J.B. \& Lleonart J., 1993. Day-night migrations by deep-sea decapod crustaceans samplings in the Western Mediterranean sea. Journal of Experimental Marine Biology and Ecology, 171: 63-73. 
Castro M., Gancho P. \& Henriques P., 1998. Comparison of several populations of Norway lobster, Nephrops norvegicus (Linnaeus, 1758), from the Mediterranean and adjacent Atlantic. A biometrics study. Scientia Marina, 62: 71-79.

CGPM/GFCM, 1982. Rapports de la quatrieme session du Comite de l'amenagement des resources, Rome, 17-18 Juin 1982, et de la Consultation technique sur la regulation de l'effort dans le pecheries au chalut en Mediterranee, Rome, 14-16 Juin 1982. FAO fisheries report 270, $83 \mathrm{pp}$.

Charuau A., 1978. Nouvelles données sur la sélectivité des chaluts en polyamide dans la pêche de la langoustine. ICES CM 1978/K: 5.17 pp.

Conand C., 1977. Contribution à l'étude du cycle sexuel et de la fécondité de la sardinelle ronde (Sardinella aurita), pêche sardinière Dakaroise en 1975 et premier semestre 1976. Cahiers ORSTOM. Serie Oceanographie, 15: 301-312.

Cristo M. \& Castro M., 2005. Field estimation of daily ration of Norway lobster (Nephrops norvegicus) in the south of Portugal. New Zealand Journal of Marine and Freshwater Research, 39: 485-491. https:// doi.org/10.1080/00288330. 2005.9517327

Dintheer C., 1982. Distribution des grands pélagiques autour de la Corse - campagne de prospections aériennes 1980. Science et Pêche, 322: 1-14.

Farmer A.S.D., 1972. The general biology of Nephrops norvegicus (Linnaeus, 1758) (Decapoda, Nephropidae) off the Isle of Man. Ph. D. Thesis, University of Liverpool, U.K.

Farmer A.S.D., 1975. Synopsis of biological data on the Norway lobster Nephrops norvegicus (Linnaeus, 1758). F.A.O. Fisheries Synopsis, 112: 1-97.

Fontaine B. \& Warluzel N., 1969. Biologie de la langoustine du golfe de Gascogne. Nephrops norvegicus (Linnaeus, 1758.). Revue des Travaux de l'Institute des Pêches Maritimes, 33: 223-246.

Froglia C. \& Gramitto M.E., 1979. An estimate of the fecundity of Norway lobster (Nephrops norvegicus) in the Adriatic Sea, Commission internationale pour 1'exploration scientifique de la mer Méditerranée, 25/26: 227-229.

Froglia C. \& Gramitto M.E., 1981. Summary of biological parameters on the norway lobster $N$. norvégiens in the Adriatic sea. FAO Fisheries Report No. 253: 165-178.

Froglia C. \& Gramitto M.E., 1988. An estimate of growth and mortality parameters for Norway lobster (Nephrops norvegicus) in the Central Adriatic Sea. FAO Fisheries and Aquaculture Report, 394: 189203.

Gulland J.A., 1983. Fish stock assessment. A manual of basic methods. Ed. John Wiley \& Sons. FAO Series on Food and Agriculture, vol.1, 223 pp.
ISTPM, 1982. Evaluation des Ressources Halieutiques de la marge continentale Algérienne. Stocks pélagiques - Stocks démersaux exploitables au chalut. Campagne Thalassa, Ichtys, Joamy 1982, 101 pp.

Jukic S., 1971. Studies on the population and the catchability of Norway lobster in the central Adriatic. Studies on the population and catchability of Norway lobster in the central. Adriatic. FAO Studies and Reviews, 48: 27-52.

Karlovac O., 1953. An ecological study of Nephrops norvegicus (Linnaeus, 1758) of the High Adriatic. Institute of Oceanography Ribarst, 5: 1-51.

Kartas F. \& Quignard J.P., 1984. La fécondité des Poissons Téléostéens. Masson Ed., Paris. 117 pp.

Kirkwood G.P., Aukland R. \& Zara S.J., 2001. Length Frequency Distribution Analysis (LFDA). Version 5.0. MRAG Ltd, London, UK.

Macher C., Guyader O., Talidec C. \& Bertignac M., 2008. A cost-benefit analysis of improving trawl selectivity in the case of discards: The Nephrops norvegicus fishery in the Bay of Biscay. Fisheries Research, 92: 76-89. https://doi.org/10.1016/j.fishres. 2007.12021

Massuti E., Guijarro B., Pomar B., Fliti K., Reghis M., Zaghdoudi S., Bouaïcha M., Ait Ferroukh B. \& Zereb N., 2003. Report of the Algeria 0203-DP campaign for the assessment of deep sea fishery resources off the coast of Algeria (South-West Mediterranean). Ministère de la Pêche et des Ressources Halieutiques (AlgerAlgérie), Secrétariat d'état chargé de la pêche maritime (Madrid-Espagne), $103 \mathrm{pp}$.

Mc Quaid N., Briggs R.P. \& Roberts D., 2006. Estimation of the size of onset of sexual maturity in Nephrops norvegicus (Linnaeus, 1758). Fisheries Research, 81: 26-36. https://doi.org/10.1016/j. fishres.2006.06. 003

Morello E.B., Antolini B., Gramitto M.E. \& Atkinson R.J.A., 2009. The fishery for Nephrops norvegicus (Linnaeus, 1758) in the central Adriatic Sea (Italy). Preliminary observations comparing bottom trawl and baited creels. Fisheries Research, 95: 325-331. https://doi.org/10.1016/j.fishres.2008.10.002

Morizur Y., Conan G., Guenole A. \& Omnes M.H., 1981. Fécondité de Nephrops norvegicus dans le Golfe de Guascogne. Marine Biology, 63: 319-324.

Morizur Y., 1981. Evolution du taux de spermatophare chez les femelles de Nephrops norvegicus (Linnaeus, 1758) (Decapoda: Reptantia) et développement ovarien. Journal of Experimental Marine Biology and Ecology, 52: 15-24.

Morizur Y., 1983. Utilisation de critères fonctionnels (présence de spermatophore, maturation des ovaires) pour la détermination de la taille et de 1' âge à maturité sexuelle des Nephrops norvegicus femelles de la région sud-Bretagne. Journal du Conseil Permanent 
International pour l'Exploration de la Mer, 41: 2836

Morizur Y., Conan G., Guenole A. \& Omnes M.H., 1978. Fécondité de Nephrops norvegicus dans le golfe de Gascogne. Marine Biology, 63: 319-324.

Mouffok S., Kherraz A., Bouras D. \& Boutiba Z., 2008. The fishery for and local distribution of Aristeus antennatus (Risso, 1816) (Crustacea: Dendrobranchiata) off western Algeria. African Journal of Aquatic Science, 33: 175-179. https://doi.org/10.2989/AJAS. 2008.33. 2.10.507.

Mytilineou C.H., Castro M., Gancho P. \& Fourtouni A., 1998. Growth studies on Norway lobster, Nephrops norvegicus (Linnaeus, 1758), in different areas of the Mediterranean Sea and the adjacent Atlantic. Scientia Marina, 62: (Suppl.1), 43-60.

Orsi Relini L. \& Relini G. 1985. Notes on the distribution, reproductive biology and fecundity of Nephrops norvegicus in the. Ligurian Sea. FAO Fish. Rep., 336:107-111.

Orsi Relini L. \& Relini G., 1989. Reproduction of Nephrops norvegicus, Linnaeus. 1758, in isothermal Mediterranean waters. In: Ryland S. \& Tyler P.A. (Eds.) Reproduction, Genetics and distributions of Marine Organisms, 23th European Marine Biology Symposium. Olsen \& Olsen . Fredensborg, 153-160.

Orsi Relini L., Zamboni A., Fiorentino F. \& Massi D., 1998. Reproductive patterns in Norway lobster (Nephrops norvegicus Linnaeus 1758, Crustacea Decapoda Nephropidae) of different Mediterranean areas. Marina de Scientia, 62 (Suppl.1): 25-41.

Pauly D. \& Moreau J., 1997. Méthodes pour l'évaluation des ressources halieutiques. Collection Politech de l'I.N.P. de Toulouse, Cépaduès-Editions, France, 288 pp.

Pauly D. \& Murno J.L., 1984. Once more on growth comparison in fish and invertebrates. Fishbyte, 2: 21.

Sarda F., 1983a. Determinación de los estados de intermuda de Nephrops norvegicus (Linnaeus, 1758.), mediante la observación de los pleópodos. Investigación Pesquera, 47: 95-112.

Sarda F., 1983b. El proceso de la regeneración de las quelas en la cigala, Nephrops norvegicus (Linnaeus, 1758). Investigación Pesquera, 47: 113-123.

Sarda F. \& Cros Y.M.L., 1984. El metabolismo del calcio y del magnesio en la cigala Nephrops norvegicus (Linnaeus, 1758), durante las etapas del ciclo de muda. Investigación Pesquera, 48: 377-397.
Sarda F., 1985. Estudio de la edad, crecimiento y frecuencia de muda, en cautividad de Nephrops norvegicus (Linnaeus, 1758) del mar Catalán. Investigación Pesquera, 49: 139-154.

Sarda F. \& Valladares F.J., 1990. Gastric evacuation of different foods by Nephrops norvegicus (Crustacea: Decapoda) and estimation of soft tissue ingested, maximum food intake and cannibalism in captivity. Marine Biology, 104: 25-30.

Sarda F., 1991. Reproduction and moult sinchronism on Nephrops norvegicus from wester Mediterranean. Crustaceana, 60: 186-199.

Sarda F. \& Lleonart J., 1993. Evaluation of the Norway lobster (Nephrops norvegicus, Linnaeus, 1758.) Resource off the "Serola" bank off Barcelona (western Mediterranean). Scientia Marina, 57: 191-197.

Sarda F., 1998. Comparative technical aspects on the fishery of Nephrops norvegicus (Linnaeus, 1758.) in the northern Mediterranean Sea. Scientia Marina, 62 (Suppl. 1): 101-106.

Sarda F., Bas C., Roldan MI., Pla C. \& Lleonart J., 1998. Enzymatic and morphometric analyses in mediterranean populations of the rose shrimp, Aristeus antennatus (Risso, 1816). Journal of Experimental Marine Biology and Ecology, 221: 131-144.

Sarda F. \& Aguzzi J., 2012. A review of burrow counting as an alternative to other typical methods of assessment of Norway lobster populations. Fish Biology and Fisheries, 22: 409-422. https://doi.org/10.1007 /s11160-011-9242-6.

Sparre P. \& Venema S.C., 1996. Introduction à l'évaluation des stocks des poissons tropicaux. Première partie: Manuel. FAO Document Technique sur les Pêches, Rome, 306: 401 pp.

Statsoft Inc., 2001. Statistica (data analysis software system), Version 6. www.statsoft.com.

Ungaro N., Marano G., Marsan R. \& Pastorelli A.M., 1999. On the reproduction of Nephrops norvegicus in the Southern Adriatic Sea: sex ratio, maturity length and potential fecundity. Crustacean Issues, 12: 553-561.

Ursin E., 1967. A mathematical model of some aspects of fish growth, respiration and mortality. Journal of the Fisheries Research Board of Canada, 24: 23552453.

Von Bertalanffy L., 1938. A quantitative theory of organic growth (inquires on growth laws II). Human Biology, 10: 181-213. 